\title{
Predator-inducible defences and local intra- population variability of the intertidal mussel Semimytilus algosus in central Chile
}

\author{
Andrés U. Caro, Juan Carlos Castilla* \\ Center for Advanced Studies in Ecology \& Biodiversity, Facultad de Ciencias Biológicas, \\ Pontificia Universidad Católica de Chile, Casilla 114-D, Santiago, Chile
}

\begin{abstract}
Predator-inducible defences have a strong influence on the expression of morphological traits of intertidal invertebrates. For instance, mussels exposed to predators often have thicker shells than non-exposed. On the intertidal rocky shores of Chile, the mussel Semimytilus algosus is a preferred prey of many carnivorous invertebrates, including the snails Nucella crassilabrum and Concholepas concholepas, and the crab Acanthocyclus gayi. Preliminary observations indicated that $S$. algosus exists as 2 morphotypes: a thick, smooth shell and a thinner, ringed shell. The thick-shell morphotype was found mostly on compact, rocky platforms, whereas the thin one was found on emergent rocks. We examined the role of invertebrate predators in determining the morphological differences observed in S. algosus as a process of defence induction. The density and size of mussel predators showed significant differences between habitats: A. gayi dominating the platforms and $N$. crassilabrum emergent rocks. C. concholepas did not show differences between habitats. Waterborne cue experiments demonstrated that the mussel shell thickness is increased by the presence of predators, especially A. gayi. Furthermore, in contrast to the other predators, A. gayi preferentially selects mussels of the thin-shell morphotype. We demonstrate the cause and effect connection between variation in mussel shell morphology in the laboratory and their associated spatial distribution in the field, as well as the ecological role played by predators. We propose that, at local scales, the distribution and abundance of predators in the field explain the inter-population morphological differences of the mussel $S$. algosus.
\end{abstract}

KEY WORDS: Predator-inducible defences $\cdot$ Shell thickness $\cdot$ Growth $\cdot$ Predator-prey interaction · Mussel $\cdot$ Semimytilus algosus

Resale or republication not permitted without written consent of the publisher

\section{INTRODUCTION}

Predator-inducible defences, which are present in numerous taxonomic groups (vertebrates, invertebrates, plants, bacteria), are caused by cues associated with predators, and may diminish the effects of subsequent predator attacks (Adler \& Harvell 1990, Harvell 1990, Tollrian \& Harvell 1999). Predators can affect a diverse array of traits in their prey: behaviour, physiology, morphology and life-history (Dodson 1989, Adler \& Harvell 1990, Lima \& Dill 1990, Skelly \& Werner 1990, Kats \& Dill 1998, Lima 1998). When predation is patchy and unpredictable, the prey may benefit from possessing defences that can be induced when needed, rather than being permanently expressed (Tollrian \& Harvell 1999). The induction of defences requires an external signal for activation and is thought to be favoured over constitutive defences when (1) the cues associated with predators are nonlethal; (2) the fitness costs are less than the benefits of the defence; (3) the probability of encountering a predator is high, but unpredictable; (4) the prey have reliable cues for detecting the presence of a predator; and (5) the presence of the predator in time and space 
is intermittent (Harvell 1986, 1990, Lively 1986a, Havel 1987, Adler \& Harvell 1990, Riessen 1992).

In marine, rocky, intertidal systems, morphological defences lowering predation success can be produced by invertebrate prey, for example gastropods (Appleton \& Palmer 1988, Palmer 1990, Trussell 1996), bryozoans (Yoshioka 1982), barnacles (Lively 1986b) and mussels (Reimer \& Tedengren 1996, Leonard et al. 1999, Reimer \& Harms-Ringdahl 2001). Mussels are prey for a variety of predators, including gastropods, crustaceans, seastars, fishes, shorebirds and mammals (Seed 1976, Menge 1978a,b, Suchanek 1978, Castilla 1981, Bahamondes \& Castilla 1986, Meire \& Ervnyck 1986, Ojeda \& Dearborn 1991). Regardless of the predation mode, these predators are able to breach the mussel's protective shell to reach the soft tissue in a variety of ways: (1) whole-animal ingestion, (2) invasion through the shell aperture, (3) breakage and (4) drilling. Whilst most marine gastropod predators drill holes through mussel shells using a combination of chemical and mechanical procedures (Castilla et al. 1979, Serra et al. 1997), crabs use their chelae and/or their mandibles to break shells (Castilla 1981, Hughes \& Seed 1981, Navarrete \& Castilla 1988). For each of the methods employed to consume mussels, there is an associated handling time, depending on (1) the morphological or behavioural resistance of the prey (e.g. the ability of the shell to resist penetration or being opened), and (2) the efficiency of the predator in overcoming the prey's resistance. Optimal foraging theory predicts that predators should prefer medium-sized mussels to smaller or larger ones, since the ratio of handling time to reward is minimised (Elner \& Hughes 1978, Hughes \& Seed 1981).

Many mussel species show considerable intra-population variation in morphological traits (i.e. shell thickness and growth) that have been explained by wave exposure (Raubenheimer \& Cook 1990, Steffani \& Branch 2003), population density, food supply (Seed 1968) and intertidal height (Franz 1993). Furthermore, classical studies have addressed this kind of variability in terms of predator-prey interactions (Kitching et al. 1959, Ebling et al. 1964). For instance, many mussels develop defence mechanisms, such as increased shell thickness (Leonard et al. 1999, Smith \& Jennings 2000), strong adductor muscles (Hancock 1965), and increased byssus thread production (Day et al. 1991, Côté 1995), to reduce the efficiency of their predators.

The mussel Semimytilus algosus (Gould, 1850) is a common inhabitant of the low rocky intertidal fringe in central Chile, distributed between Ecuador and Chiloe Island (approximately $42^{\circ} \mathrm{S}$ ). In central Chile (around $33^{\circ} \mathrm{S}$ ), this mussel is one of the preferred prey for a guild of intertidal carnivorous predators, including the gastropods Concholepas concholepas (Bru- guière,1789), Nucella crassilabrum (Pallas, 1774) and Crassilabrum crassilabrum (Sowerby, 1834); the echinoderms Heliaster helianthus (Lamarck, 1816) and Stichaster striatus (Müller \& Troschel, 1840); and the crustaceans Acanthocyclus gayi (Milne Edwards \& Lucas, 1844) and A. hassleri (Rathbun, 1898) (Castilla 1981, Méndez \& Cancino 1990, Soto 1996, 2001). At Matanzas (central Chile), 2 contrasting habitats can be distinguished: (1) extensive, compact, rocky platforms, and (2) small, emergent, disconnected rocks, surrounded by sand. Preliminary observations have shown that there are morphological differences in $S$. algosus from the 2 habitats (S. Navarrete pers. comm.). Mussels on emergent rocks have thick, uniformly yellow shells with a smooth surface, while those on platforms have thinner, uniformly brown shells with a ringed surface. However, these differences are not evident in juvenile specimens (shell length $<10 \mathrm{~mm}$ ). Although $S$. algosus shows these strikingly different morphologies, no studies in Chile have addressed the ecological causes. The objective of this work was to evaluate the effect of predation risk on the growth and shell thickness of $S$. algosus, and to address the interaction between this mussel and its main predators. Based on laboratory experiments, we hypothesise that intra-population differences in the shell thickness of $S$. algosus are caused by sub-lethal predator-prey interactions, via a process of defence induction. Therefore, differences in the density and spatial distribution of the mussel's predators between habitats may constitute an important factor influencing the pattern of shell thickness in the field. We propose that the production of defensive morphotypes has an adaptive value for this mussel, since predators have a preference for mussels with thinner shells.

\section{MATERIALS AND METHODS}

Locality. The study was conducted in Matanzas $\left(33^{\circ} 58^{\prime} \mathrm{S}, 71^{\circ} 53^{\prime} \mathrm{W}\right)$, an exposed rocky shore on the coast of central Chile. Matanzas has a fragmented intertidal zone with 2 different habitats, extending approximately $2 \mathrm{~km}$ along the shore. One is characterised by emergent rocks of relatively small area $(\sim 1$ to $3 \mathrm{~m}^{2}$ ), separated from each other by sand. The second habitat is characterised by compact and extensive rocky platforms ( 15 to $\left.30 \mathrm{~m}^{2}\right)$. The mussel Semimytilus algosus inhabits the low intertidal fringe in both habitats, forming dense monolayer patches. Sand scour difference between habitats was not tested.

We worked at 3 sites, each containing both habitats, and characterised their wave exposure, registering maximum wave velocity over a 4 d period (July 12 to 15, 2003). Five dynamometers (Bell \& Denny 1994) per 
habitat were screwed down in the low intertidal zone at each site. Daily maximum wave force was registered in the field, as drag force $(\mathrm{N})$, using a line spring scale $\left(\right.$ PESOLA $^{\oplus}$, accuracy $\left.=0.075 \mathrm{~N}\right)$. Drag force data were transformed to values of velocity $\left(\mathrm{m} \mathrm{s}^{-1}\right)$ using the calibration curve previously obtained from a power fit (see Castilla et al. 1998). A 2-way ANOVA for maximum wave velocity data was performed on $\ln (x)$ transformed data. Days were considered as a blocking factor.

Morphological analysis. We evaluated the existence of shell morphological differences in Semimytilus algosus through the collection of mussels during 4 seasonal sampling events over a 1 yr period. During each sampling, three $10 \times 10 \mathrm{~cm}$ quadrats were thrown haphazardly in each habitat ( $\mathrm{n}=1$ quadrat per habitat per site) in the low intertidal fringe (maximum tidal range: $1.7 \mathrm{~m}$ ). Mussels within each quadrat were collected by scraping the rock with a metal spatula. Samples were frozen $\left(-18^{\circ} \mathrm{C}\right)$ prior to analysis. To evaluate mussel shell thickness and compare mussel characteristics between habitats, we haphazardly sub-sampled 30 mussels (shell length $>10 \mathrm{~mm}$ ) per quadrat. Mussel shell mass was evaluated by dissecting the mussels into shell and flesh components; shells were oven-dried at $70^{\circ} \mathrm{C}$ for $48 \mathrm{~h}$, and weighed (precision: $\pm 0.001 \mathrm{~g}$ ). Shell thickness was calculated using a thickness index (Ti): $\mathrm{Ti}=$ weight of right valve $(\mathrm{g}) /$ planar valve surface $\left(\mathrm{mm}^{2}\right)$ (Guiñez 1996). To measure the planar valve surface area, we took high-resolution pictures of the right mussel valve for 30 individuals per quadrat, using a digital camera (Kodak ${ }^{\mathrm{TM}}$ digital science model DC210 Zoom Camera). Pictures were converted to binary files and the surface area of each valve was measured separately using SigmaScan ${ }^{\circledR}$ Pro 5.0 software (SPSS 1999). We decided not to make direct measurements of valve thickness, because there is interdependence among the multiple measurements for a single valve. The calculated thickness index solved this problem and allowed us to perform parametric statistical tests. For mussel shell thickness data we performed a 3-way, blocked, mixed ANCOVA (analysis of covariance), with Season and Habitat Type as fixed factors and Site as a random factor. We used shell weight as the dependent variable and shell surface area as a covariate. Differences in the Ti were analysed using a 3-way, blocked, mixed ANOVA, with Season and Habitat Type as fixed factors and Site as a blocking factor. Mussel thickness index data were $\ln (x)$ transformed to meet assumptions of normality and homoscedasticity of variances. For both analyses, we assumed no interaction effects between blocks and the other factors.

Predator density and size. Through bi-monthly determinations (May 1999 to May 2000), we evaluated the density of intertidal invertebrate predators. For each sample we recorded the number and sizes of predators (body size $>10 \mathrm{~mm}$ ) in the low intertidal fringe in 18 haphazardly placed $50 \times 50 \mathrm{~cm}$ quadrats (i.e. 3 replicates in each habitat per site). Site was considered as a blocking factor. Body sizes were measured only twice (November 1999 and March 2000) to minimise potential effects of disturbance on the system. For gastropods, we measured maximum shell length and for crabs, the maximum carapace width, using vernier callipers. Measurements were made in the field and specimens returned to their habitat.

Multiple-choice feeding preference. Feeding preferences of 3 Semimytilus algosus predators, i.e. Nucella crassilabrum, Concholepas concholepas and Acanthocyclus gayi, were investigated via multiplechoice laboratory experiments, using thin and thick mussel morphotypes. Both morphotypes were held in the same aquarium and offered simultaneously to the predators. We hypothesised that predators would prefer mussels with thin shells. The predators and mussels used in the experiments were collected from the study locality on May 15, 2000. Prior to experimentation, predators and mussels were maintained under laboratory conditions for a $1 \mathrm{wk}$ period in separate aquaria. Experiments were run simultaneously for 10 consecutive d using the 3 predators. Each experimental unit consisted of a plastic aquarium (2 l), containing 1 predator and 10 adult mussels (shell length 25 to 27 $\mathrm{mm}$ ) of each morphotype ( $\mathrm{n}=10$ aquaria per predator species). Aquaria received constant, continuously flowing seawater and air during the experiment and the temperature ranged between 14 and $16^{\circ} \mathrm{C}$. We recorded the number of mussels per morphotype consumed per predator per day in each aquarium. To maintain a constant probability of predators encountering a prey, the consumed mussels were replaced daily by fresh mussels of the same morphotype. To evaluate predator-independent mortality, control mussels were kept in aquaria without predators (controls). Several authors have described deficiencies in the design and analysis of multiple-choice feeding-preference experiments (Peterson \& Renaud 1989, Roa 1992, Manly 1993, Lockwood 1998, Jeffrey et al. 2004). In this work, we followed Roa's (1992) methodology and used a 1-sample Hotelling's T-squared test for statistical analysis.

Predator water-borne cues. To test the hypothesis that Semimytilus algosus shell thickness is the result of sub-lethal predator-prey interactions, we exposed juvenile mussels (shell length 7.0 to $10.0 \mathrm{~mm}$ ) to waterborne cues from the crab Acanthocyclus gayi and the gastropods Concholepas concholepas and Nucella crassilabrum over a 5 mo period, and evaluated the effect on $S$. algosus shell growth and thickness. On December 24, 2000 we collected 720 juvenile S. algo- 


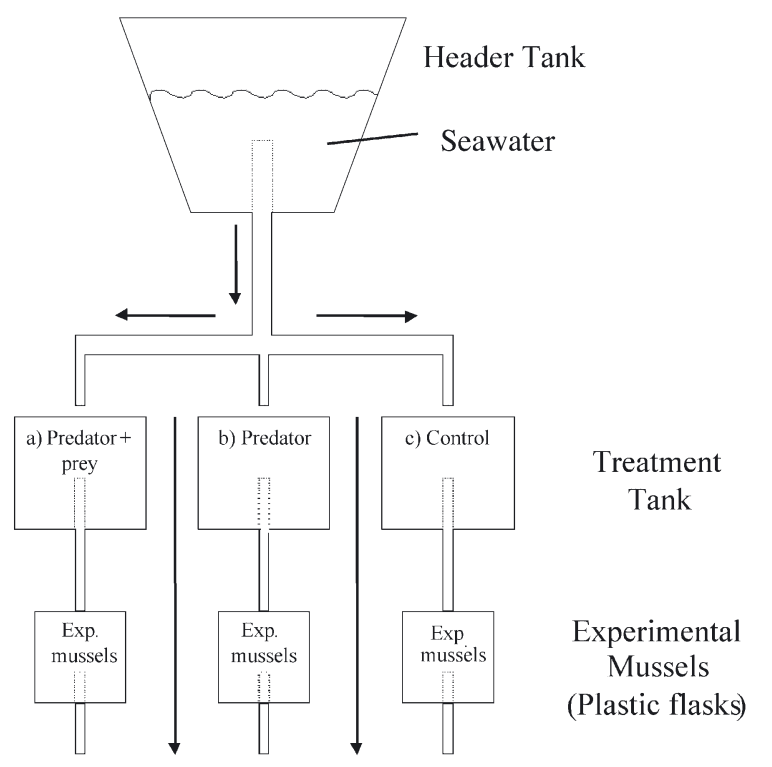

Fig. 1. Simplified scheme of the system designed for experiments on predator water-borne cues. Each plastic flask is an experimental unit (=20 juvenile Semimytilus algosus). The complete design included 36 experimental units $(n=4$ per treatment per predator species)

sus from the study locality and marked them with a coloured and numbered bee tag (C. Graze, Germany), glued to the right valve with cyanoacrylate glue (Poxipol $^{\mathrm{TM}}$ ). Prior to experimental treatments, we recorded the maximum shell length of mussels using digital callipers. The experimental mussels were held in plastic flasks and exposed to effluent arriving from 1 of 3 treatments: (1) tank with predator + mussels (i.e. 1 predator with 5 mussels as prey, replaced daily according to consumption); (2) tank with predator alone (i.e. 1 predator specimen); and (3) tank with mussels (i.e. 5 adult mussels and no predator) (Fig. 1). Experiments were performed simultaneously for the 3 predator species $(n=4$ replicated plastic flasks per effluent treatment per predator species; total of 36 independent flasks). Treatments were spatially arranged at random. Each flask received flowing seawater (filtered through a coarse sand filter) at a rate of $0.251 \mathrm{~min}^{-1}$ and water flow was verified every $12 \mathrm{~h}$. Each plastic flask (volume $=0.4$ l) contained 20 mussels and was connected to the treatment tank by a PVC tube (length $=7 \mathrm{~cm}_{i}$ diameter $=2 \mathrm{~cm}$ ) (Fig. 1). Mussels were not artificially fed. Every $15 \mathrm{~d}$ we replaced the predator and prey specimens in the tank treatments with freshly collected specimens from Matanzas. Predators were fasted for $1 \mathrm{wk}$ prior to their introduction into the experimental system. After 5 mo of exposure to the treatments we measured the mussels' maximum shell length, width and height. We also calculated the thickness index (Ti) and evaluated the effect of each treatment on $\mathrm{Ti}$ and growth using a 3-way nested ANCOVA, considering Predator species (3 levels), Effluent ( 3 levels) and Replica as fixed factors, and the initial shell length as a covariable.

\section{RESULTS}

\section{Exposure}

The maximum average daily wave velocity registered in the platform habitats was $3.26 \pm 0.30 \mathrm{~m} \mathrm{~s}^{-1}$, and in the emergent rock habitats was $3.22 \pm 0.23 \mathrm{~m} \mathrm{~s}^{-1}$ (mean $\pm 1 \mathrm{SE}$ ). Wave velocity was not significantly different between habitats (Table 1).

\section{Morphological analysis}

Mussels from the platform habitat had a greater weight per unit surface area than mussels from the emergent rocks (Fig. 2). Shell weight was not signifi-

Table 1. Three-way nested ANOVA for maximum wave velocity at 3 sites in Matanzas ( $\mathrm{df}=$ degrees of freedom, $\mathrm{MS}=$ mean square, $F=$ value of the $F$-statistics, $\mathrm{p}=\mathrm{p}$-value)

\begin{tabular}{|lrcrc|}
\hline Source of variation & df & MS & $F$ & $\mathrm{p}$ \\
\hline Day & 3 & 0.7141 & 58.83 & 0.004 \\
Site & 2 & 0.1282 & 10.56 & 0.044 \\
Habitat (Site) & 3 & 0.0121 & 0.27 & 0.847 \\
Day $\times$ Site & 6 & 0.0455 & 1.47 & 0.197 \\
Residual & 105 & 0.0310 & & \\
\hline
\end{tabular}

Table 2. Nucella crassilabrum, Concolepas concholepas and Acanthocyclus gayi. Monthly average density (ind $\mathrm{m}^{-2}$ ) of predators in each habitat (ER = emergent rock habitat; $\mathrm{P}$ = platform habitat) in Matanzas during May 1999 to May 2000. Mean (SE)

\begin{tabular}{|c|c|c|c|c|c|c|}
\hline & \multicolumn{2}{|c|}{ N. crassilabrum } & \multicolumn{2}{|c|}{ C. concholepas } & \multicolumn{2}{|c|}{ A. gayi } \\
\hline & ER & $\mathrm{P}$ & ER & $\mathrm{P}$ & ER & $\mathrm{P}$ \\
\hline May 99 & $7.5(1.0)$ & $3.2(0.8)$ & $2.1(0.8)$ & $4.0(0.1)$ & $0.0(0.0)$ & $5.5(0.4)$ \\
\hline Jul 99 & $9.1(0.1)$ & $5.9(0.6)$ & $3.0(1.2)$ & $2.6(1.8)$ & $0.8 \quad(0.2)$ & $7.6(1.0)$ \\
\hline Sep 99 & $12.8(0.3)$ & $8.4(1.0)$ & $5.1(0.1)$ & $4.1 \quad(0.2)$ & $0.8(0.4)$ & $8.0(1.5)$ \\
\hline Nov 99 & $12.6(0.9)$ & $11.8(0.1)$ & $5.2(1.1)$ & $3.9(0.6)$ & $0.6(0.2)$ & 8.4 (1.9) \\
\hline Jan 00 & $12.2(0.6)$ & $10.8(1.2)$ & $4.2(0.9)$ & $6.5(1.6)$ & $0.0(0.0)$ & $5.5(0.4)$ \\
\hline Mar 00 & $11.0(0.8)$ & $6.8(1.0)$ & $3.2(1.1)$ & $3.2(1.1)$ & $0.6(0.2)$ & $5.9(0.2)$ \\
\hline May 00 & $7.2(0.8)$ & $4.2(0.1)$ & $2.1(1.2)$ & $3.0(0.2)$ & $0.0(0.0)$ & $3.0(0.2)$ \\
\hline
\end{tabular}




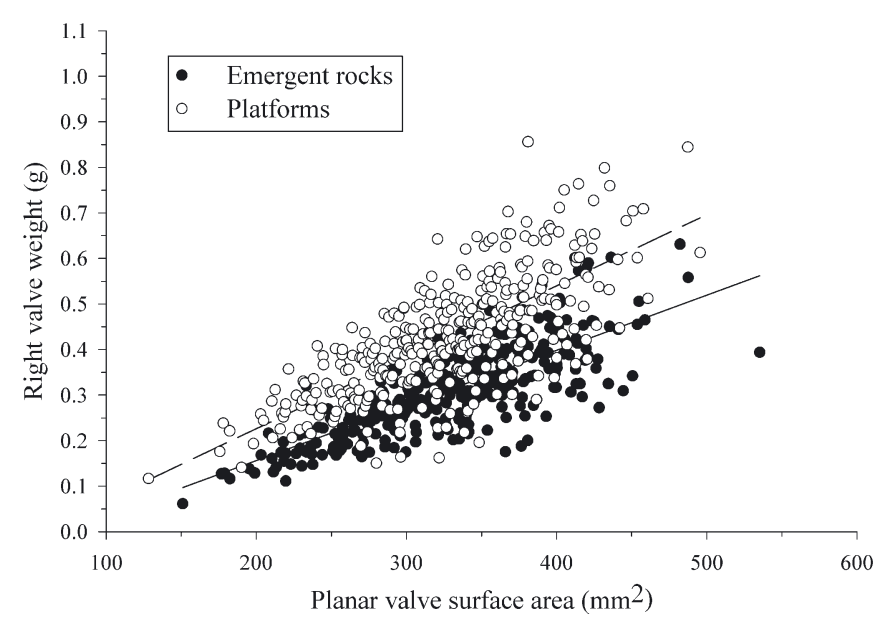

Fig. 2. Semimytilus algosus. Shell thickness. Right valve weight $(\mathrm{g})$ versus planar valve surface area $\left(\mathrm{mm}^{2}\right)$ relationship of mussel shell ( $\mathrm{n}=360$ mussels per habitat). The continuous line represents the linear regression for mussels associated with emergent rock habitat (equation: valve weight $=$ $0.001211 \times$ planar valve surface area $\left.-0.0855 ; r^{2}=0.58\right)$ and the segmented line represents the linear regression for mussels in the platform habitat (equation: valve weight = $0.001567 \times$ planar valve surface area $-0.0870 ; \mathrm{r}^{2}=0.52$ )

cantly affected by the principal effect of Site or its interactions ( $p>0.5)$, but was significantly affected by Habitat Type (ANCOVA, $F_{1,2}=722.53, p=0.001$; Fig. 2). The thickness index was significantly greater (by about $37 \%$ ) for mussels from the platform habitat compared with those on emergent rocks (ANOVA, $F_{1,2}=695.79, \mathrm{p}=0.001$ ).

\section{Predator density and size}

The density of Nucella crassilabrum was significantly greater on the emergent rock habitat than on the platforms $\left(F_{1,2}=58.36, \mathrm{p}=0.017\right.$; Table 2$)$. The density of Concholepas concholepas did not show significant differences between habitats $\left(F_{1,2}=0.245, \mathrm{p}=\right.$ 0.670 ; Table 2), reaching densities of about 4 individuals $\mathrm{m}^{-2}$ at both habitats. Acanthocyclus gayi had a different pattern, being 10 times more abundant on the platform habitat than on the emergent rocks, reaching average densities of 6 individuals $\mathrm{m}^{-2}$ on the former $\left(F_{1,2}=73.662, \mathrm{p}=0.013 ;\right.$ Table 2$)$.

For Nucella crassilabrum, the largest individuals were associated with the emergent rock habitat (ANOVA, $\left.F_{1,52}=9.39, \mathrm{p}=0.0035\right)$. Concholepas concholepas sizes did not differ significantly between habitats (ANOVA, $F_{1,22}=3.17, \mathrm{p}=0.089$ ) or between sampling dates (ANOVA, $F_{1,22}=3.55, \mathrm{p}=0.072$ ). During the sampling of predator size, we did not record sufficient numbers of Acanthocyclus gayi individuals in the emergent rock habitat to allow a comparison between habitats; in the platform habitat, A. gayi did not differ significantly among sampling dates (ANOVA, $F_{1,15}=0.10, \mathrm{p}=0.750$ ).

\section{Multiple-choice feeding preference}

Out of the 3 predators studied, the crab Acanthocyclus gayi had the fastest total (thick and thin morphotypes) daily mussel consumption rate, averaging 1.99 individuals per day. The average rates for Concholepas concholepas and Nucella crassilabrum were 1.86 and 0.99 mussels, respectively. The crab A. gayi showed a selective foraging behaviour, indicated by the highly significant differences between the consumption rates of the different Semimytilus algosus morphotypes (Hotelling's T-squared $=140.00, \mathrm{p}<0.001 ;$ Fig. 3). C. concholepas and $N$. crassilabrum were less selective, consuming morphotypes of both mussels at similar rates (Fig. 3).

\section{Predator water-borne cues}

Fig. 4 shows the effect of each predator on the shell thickness of juvenile Semimytilus algosus. Thickness indexes showed significant differences for the interaction Predator $\times$ Effluent $(p<0.001$; Table 3A). This interaction precludes an analysis of main effects. Therefore, for each Effluent, we compared the differential effects among predator treatments, using the

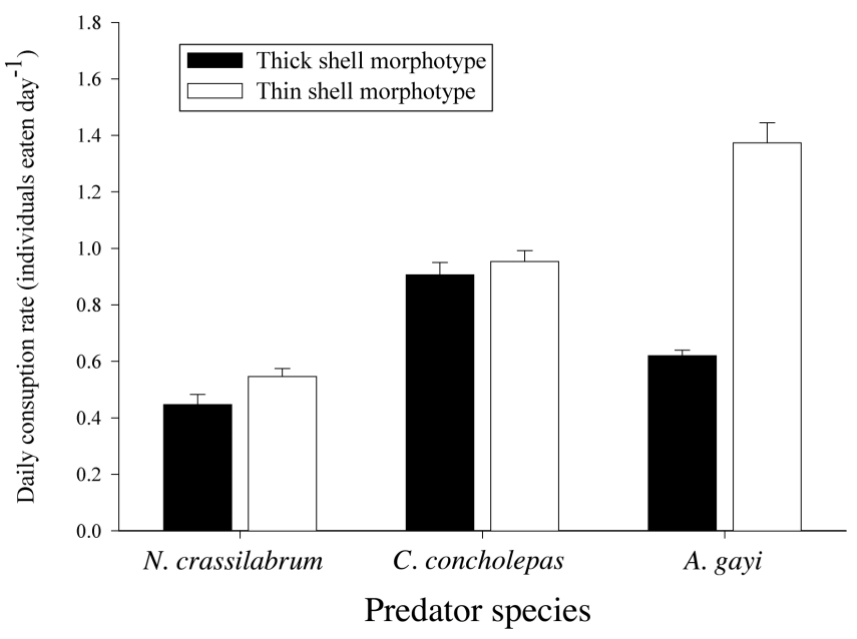

Fig. 3. Nucella crassilabrum, Concolepas concholepas and Acanthocyclus gayi. Daily consumption rates in the multiplechoice feeding-preference experiment on the 2 mussel morphotypes: thick-shell morphotype (black bars) and thin-shell morphotype (white bars). The bars represent means $+1 \mathrm{SE}$ for 10 independent experimental units 


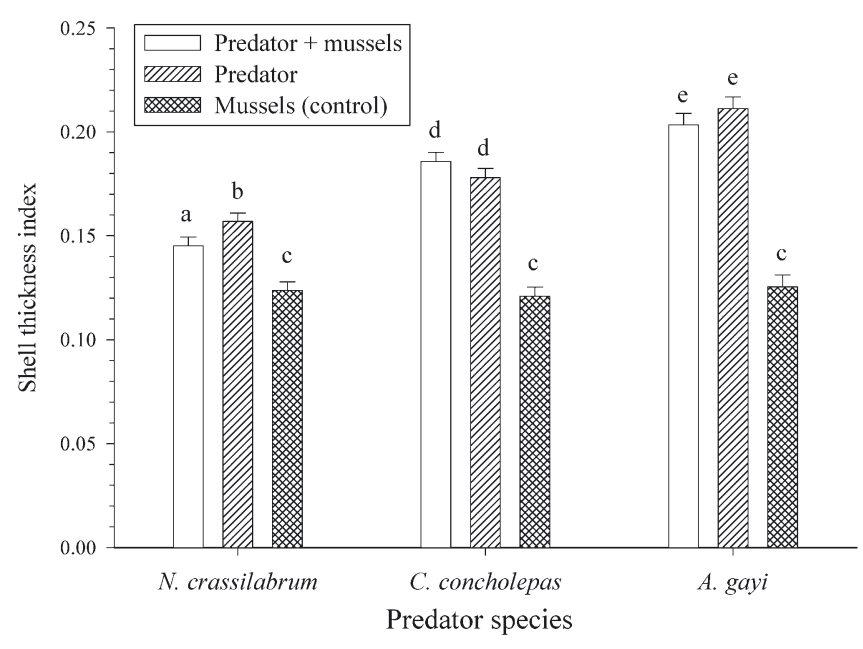

Fig. 4. Semimytilus algosus. Shell thickness of juveniles in predator water-borne cue experiment. The bars represent means +1 SE for 4 independent experimental units. Treatments sharing the same letter are not significantly different ( $p>0.05$, Tukey's HSD test adjusted for multiple comparisons)

SLICE option of PROC GLM (SAS 1996). The predator + mussels and predator treatments showed significant differences among Predator ( $p<0.001$; Table 3B), but the mussels treatment (control) did not $(\mathrm{p}=0.784$; Table 3B). Of the 3 predators tested, the crab Acanthocyclus gayi induced the largest increase in $S$. algosus shell thickness. Experimental mussels exposed to effluents from this crab developed shells with a thickness index greater than $0.20 \mathrm{~g} \mathrm{~mm}^{-2}$. In contrast, Nucella crassilabrum induced the least morphological defence from its prey. A posteriori analyses indicated that there were significant differences between the predator + mussels treatment and the predator treatment for $N$. crassilabrum ( $\mathrm{p}=0.012$, Tukey's HSD test adjusted for multiple comparisons; Fig. 4). For Concholepas concholepas and $A$. gayi treatments, however, there were no statistical differences between these 2 effluent treatments ( $p=$ 0.321 and $p=0.109$, respectively, Tukey's HSD test; Fig. 4). For all predators, we detected significant differences in $S$. algosus shell thickness among the treatments that contained predators (Treatments 1 and 2) versus the treatment without predator (Treatment 3).

The presence of water-borne cues from the 3 predator and predator + mussel treatments produced a decrease in Semimytilus algosus shell growth (Fig. 5). Since the Predator $\times$
Effluent interaction was statistically significant $(\mathrm{p}<$ 0.001; Table 4A), we again compared the differential effects of each effluent treatment among Predator, using the SLICE option of PROC GLM (SAS 1996). The predator + mussels and predator treatments showed significant differences among Predator $(p<0.001$; Table 4B), but the mussel (control) treatment did not ( $p=0.438$; Table 4B). S. algosus exposed to the Acanthocyclus gayi + mussels treatment had the smallest shell growth (Fig. 5). A posteriori analyses indicated that, for A. gayi treatments, there were statistical differences among the 3 effluents treatments $(\mathrm{p}<0.01$, Tukey's HSD test; Fig. 5). Concholepas concholepas effluent produced only a small decrease in the growth of $S$. algosus in comparison with the control treatment; but there was a significant difference between the predator and control treatments $(\mathrm{p}=0.015$, Tukey's HSD test; Fig. 5). For Nucella crassilabrum and C. concholepas, the results did not show significant differences between the predator + mussels and predator treatments ( $p>0.1$, Tukey's HSD test; Fig. 5).

\section{DISCUSSION}

In laboratory experiments, the mussel Semimytilus algosus developed different morphological traits when exposed to different predator effluents. S. algosus exposed to water-borne cues from 3 predators, Acanthocyclus gayi, Concholepas concholepas and Nucella crassilabrum, showed a significant increment in shell thickness, accompanied with a reduction in growth. An increase in mussel shell thickness in response to preda-

Table 3. Semimytilus algosus. Three-way nested ANCOVA for shell thickness (Thickness index) in predator water-borne cue experiment. Initial shell length was used as the covariate $(\mathrm{df}=$ degrees of freedom, $\mathrm{SS}=$ sums of squares, $\mathrm{MS}=$ mean square, $F=$ value of the $F$-statistics, $p=p$-value)

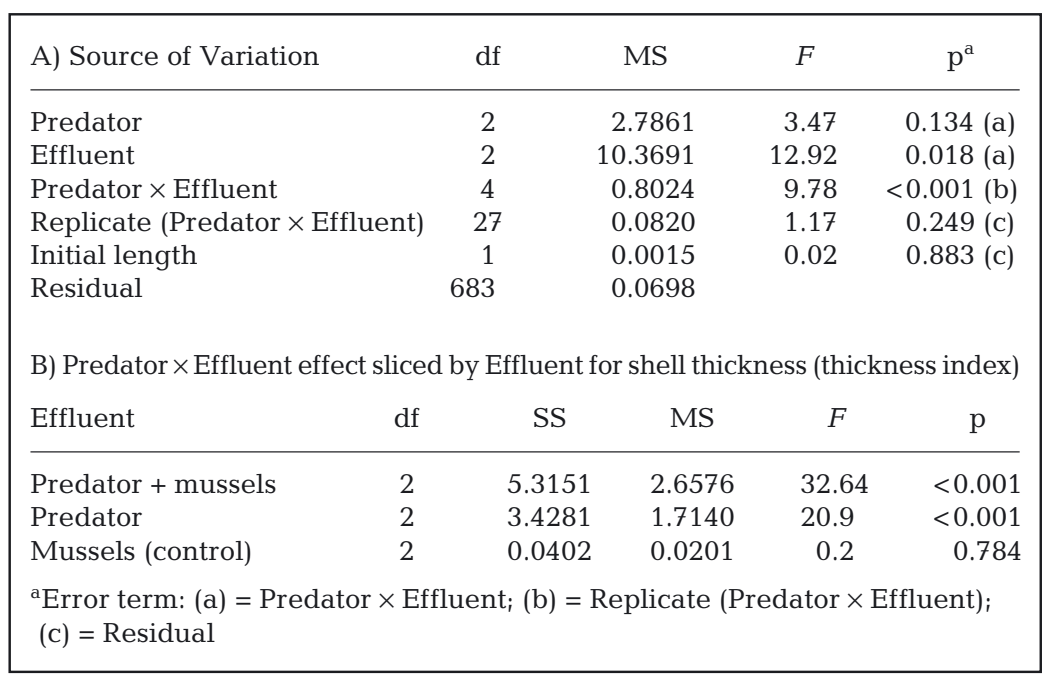




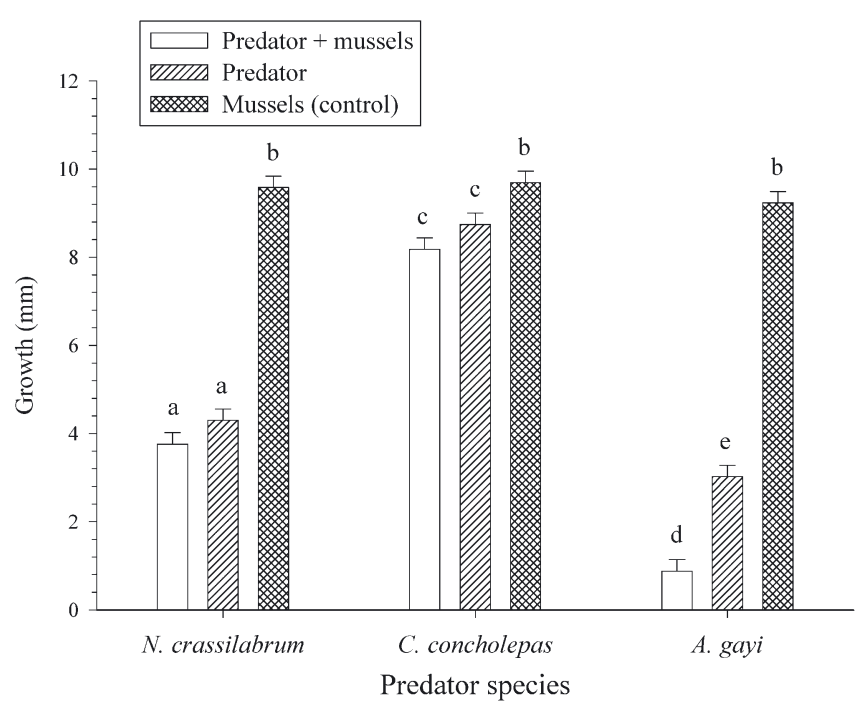

Fig. 5. Semimytilus algosus. Growth of juveniles in predator water-borne cue experiment. The bars represent means +1 SE for 4 independent experimental units. Treatments sharing the same letter are not significantly different $(p>$ 0.05, Tukey's HSD test adjusted for multiple comparisons)

tor effluents has been demonstrated for Mytilus edulis exposed to water-borne cues from crabs (Leonard et al. 1999, Smith \& Jennings 2000, Reimer \& HarmsRingdahl 2001), whelks (Smith \& Jennings 2000) and starfishes (Reimer \& Tedengren 1996, Reimer \& HarmsRingdahl 2001). Mussel shell-thickness variation is a common defence response to predation risk, independent of predator type or their mode of attack (Smith \& Jennings 2000). Furthermore, it is noticeable that mussel defence responses are induced even by predators that do not break or perforate the mussel shell to gain access to the soft tissue (e.g. starfish). M. edulis produces thicker shell lips in response to drilling and crushing predators, but increases in shell thickness are greater in the presence of a perforating gastropod predator (Smith \& Jennings 2000). In the same vein, $S$. algosus developed different shell thickness responses depending on the kind of predator tested. Water-borne cues from the shell-crushing crab Acanthocyclus gayi caused the greatest increases, while the smallest increment was caused by cues from the whelk Nucella crassilabrum.

Our results thus show that the attack modes of predators on mussels may modify the magnitude of the mussel defence response. In the laboratory, the thin-shell morphotype of Semimytilus algosus was preferred by the crab Acanthocyclus gayi; however, the other 2 predators ate both shell morphotypes indiscriminately (Fig. 3). This difference may be related to the predator's mode of attack. For those that break mussel shells, the thickness may be an important factor determining handling time. In fact, laboratory experiments show that the crab A. gayi handles its prey for several minutes while trying to break its shell, and if the manipulation period lapses without success, the crab searches for another mussel. A. gayi's handling time is positively correlated with shell thickness (A.C. pers. obs.). Thus, the phenotypic plasticity of mussel shell morphological traits (e.g. thickness) may constitute a strong source of intra-populational variation, since it may increase survival under field conditions. Mussels in the population which produce thicker shells when faced with predation risk should have a higher survival probability than those not able to do so or that are slow responders. On the other hand, if predators are distributed unequally in the field (i.e. due to the availability of different microhabitats), it can be hypothesised that their induction of defences in $S$. algosus would explain the inter-population phenotypic differences in mussel shell thickness observed in the field. In fact, in the platform habitat at Matanzas, where the crab A. gayi is abundant (Table 2), the mussel population is dominated by the thick-shell morphotype; whereas emergent rock habitats, where the crabs are scarce, are dominated by the thin-shell $S$. algosus morphotype.

Inter-habitat differences in shell morphology may also result from different local-scale physical processes, such as the effect of wave exposure (Rauben-

Table 4. Semimytilus algosus. Three-way nested ANCOVA for shell growth in predator water-borne cue experiment. Initial length was used as the covariate. Abbreviations as in Table 3

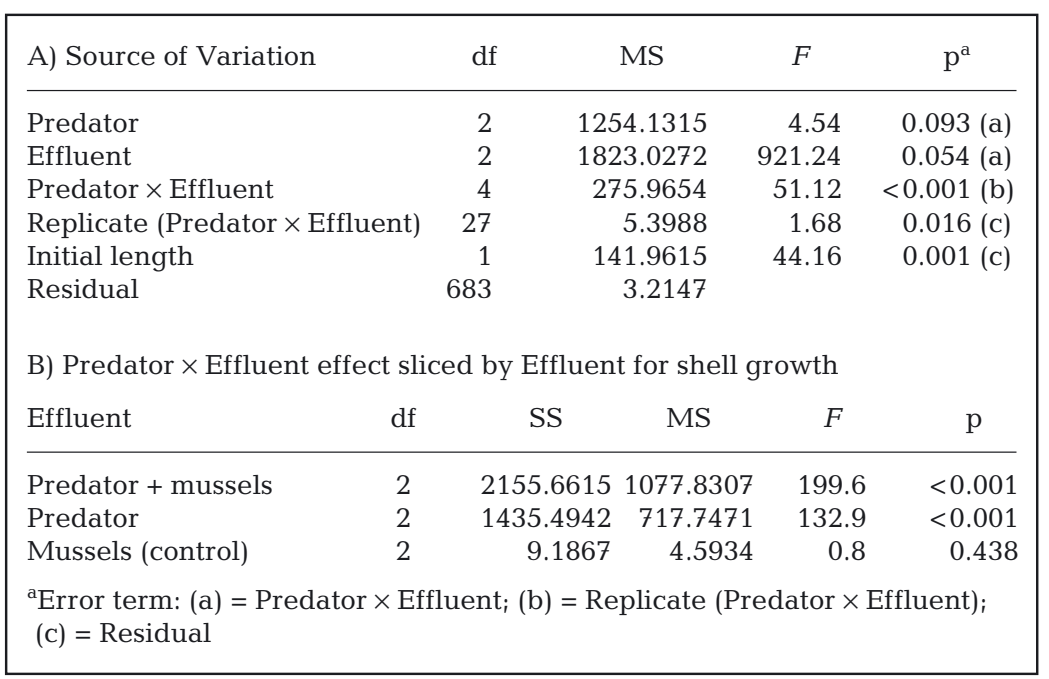


heimer \& Cook 1990, Guiñez 1996). However, our results demonstrate that the wave exposure at Matanzas did not vary significantly between habitats (Table 1); therefore, the most plausible cause for Semimytilus algosus inter-habitat shell morphology differences appears to be biotic variables. Life-history trade-offs in growth (Leonard et al. 1999) and reproductive rates (Lively 1986b) may accompany predatorinducible defences. For instance, our results show one such trade-off in the presence of predators, i.e. an increase in $S$. algosus shell thickness is accompanied by a decrease in shell growth. Apparently, predation risks provoke changes in resource partitioning of mussel shell production, giving a heavier weight to shell thickness than to linear growth, therefore diminishing the efficiency of predators.

Acknowledgements. We thank Dr. S. Navarrete, Head of the Estación Costera de Investigaciones Marinas in Las Cruces for use of laboratory facilities. D. Espinoza assisted us with the analysis of feeding-preference experiments. We sincerely thank V. A. Gutiérrez, R. Elgueta, R. Venegas, R. Soto, A. Sotomayor and G. Julio for field and laboratory assistance. P. Neill, B. Kelaher, P. Manríquez, J. M. Fariña and 3 anonymous reviewers suggested important modifications to different versions of this manuscript. The present work was supported by funds from the Pew Charitable Trust to J.C.C. The paper was completed during the tenure of FONDAP-FONDECYT grant 1501-0001 to the Center for Advanced Studies in Ecology \& Biodiversity, F. C. Biológicas, P. U. Católica de Chile.

\section{LITERATURE CITED}

Adler F, Harvell CD (1990) Inducible defenses, phenotypic variability and biotic environments. Trends Ecol Evol 5: 407-410

Appleton RD, Palmer AR (1988) Water-borne stimuli released by predatory crabs and damaged prey induce more predator-resistant shells in a marine gastropod. PNAS 85: 4387-4391

Bahamondes I, Castilla JC (1986) Predation of marine invertebrates by the Kelp Gull Larus dominicanus in an undisturbed intertidal rocky shore of central Chile. Rev Chil Hist Nat 59:65-72

Bell EC, Denny MW (1994) Quantifying 'wave exposure': a simple device for recording maximum velocity and results of its use at several field sites. J Exp Mar Biol Ecol 181: 9-29

Castilla JC (1981) Perspectivas de investigación en estructura y dinámica de comunidades intermareales rocosas de Chile Central. II. Depredadores de alto nivel trófico. Medio Ambiente 5:190-215

Castilla JC, Guisado C, Cancino J (1979) Aspectos ecológicos y conductuales relacionados con la alimentación de Concholepas concholepas (Mollusca: Gastropoda: Muricidae). Biología Pesquera, Chile 12:99-114

Castilla JC, Steinmiller DK, Pacheco C (1998) Quantifying wave exposure daily and hourly on the intertidal rocky shore of central Chile. Rev Chil Hist Nat 71:19-25

Côté IM (1995) Effects of predatory crab effluents on byssus production in mussels. J Exp Mar Biol Ecol 188:233-241
Day RW, Barkai A, Wickens PA (1991) Trapping of three drilling whelks by two species of mussels. J Exp Mar Biol Ecol 149:109-122

Dodson S (1989) Predator-induced reaction norms. BioScience 39:447-452

Ebling FJ, Kitching JA, Muntz L, Taylor CM (1964). The ecology of Lough Ine. XIII: experimental observations of the destruction of Mytilus edulis and Nucella lapillus by crabs. J Anim Ecol 33:73-82

Elner RW, Hughes RN (1978) Energy maximization in the diet of the shore crab, Carcinus maenas. J Anim Ecol 47: $103-116$

Franz DR (1993) Allometry of shell and body weight in relation to shore level in the intertidal bivalve Geukensia demissa (Bivalvia: Mytilidae). J Exp Mar Biol Ecol 174: 193-207

Guiñez R (1996) Dinámica poblacional del chorito maico, Perumytilus purpuratus (Lamarck, 1819) (Bivalvia: Mytilidae), en gradientes de exposición al oleaje. PhD thesis, Pontificia Universidad Católica de Chile, Santiago

Hancock DA (1965) Adductor muscle size in Danish and British mussels and its relation to starfish predation. Ophelia 2:253-267

Harvell CD (1986) The ecology and evolution of inducible defenses in a marine bryozoan: cues, costs, and consequences. Am Nat 128:810-823

Harvell CD (1990) The ecology and evolution of inducible defenses. Q Rev Biol 65:323-340

Havel J (1987) Predator-induced defenses: a review. In: Kerfoot WC, Sih A (eds) Predation: direct and indirect impacts on aquatic communities. University Press of New England, Hanover, NH, p 263-278

Hughes RN, Seed R (1981) Size selection of mussels by the blue crab Callinectes sapidus: energy maximizer or time minimizer. Mar Ecol Prog Ser 6:83-89

Jeffrey SP, LeBlanc WG, Maciá S (2004) Design and analysis of multiple choice feeding preference data. Oecologia 138: $1-4$

Kats LB, Dill LM (1998) The scent of death: chemosensory assessment of predation risk by prey animals. Ecoscience 5:361-394

Kitching JA, Sloane JF, Ebling FJ (1959) The ecology of Lough Ine. VIII. Mussels and their predators. J Anim Ecol 28:331-341

Leonard GH, Bertness MD, Yund PO (1999) Crab predation, waterborne cues and inducible defenses in the blue mussel, Mytilus edulis. Ecology 80:1-14

Lima SL (1998) Non-lethal effects in the ecology of predator-prey interactions. BioScience 48:25-34

Lima SL, Dill LM (1990) Behavioral decisions made under the risk of predation: a review and prospectus. Can J Zool 68: $619-640$

Lively CM (1986a) Canalization versus developmental conversion in a spatially variable environment. Am Nat 128 : $561-572$

Lively CM (1986b) Predator-induced shell dimorphism in the acorn barnacle Chthamalus anisopoma. Evolution 40: $232-242$

Lockwood III JR (1998) On the statistical analysis of multiplechoice feeding preference experiments. Oecologia 116: $475-481$

Manly BF (1993) Comments on design and analysis of multiple-choice feeding-preference experiments. Oecologia 93: 149-152

Meire PM, Ervnyck A (1986) Are oystercatchers (Haematopus astralegus) selecting the most profitable mussels (Mytilus edulis)? Anim Behav 34:1427-1435 
Méndez MA, Cancino JM (1990) Preferencias alimentarias de ejemplares postmetamórficos y juveniles de Concholepas concholepas (Bruguière1789). Rev Biol Mar 25:109-120

Menge BA (1978a) Predation intensity in a rocky intertidal community: effects of an algal canopy, wave action and desiccation on predator feeding rates. Oecologia 34:17-35

Menge BA (1978b) Predation intensity in a rocky intertidal community. Relation between predator foraging activity and environmental harshness. Oecologia 34:1-16

Navarrete SA, Castilla JC (1988) Foraging activities of Chilean intertidal crabs Acanthocyclus gayi MilneEdwards et Lucas and A. hassleri Rathbun. J Exp Mar Biol Ecol 118:115-136

Ojeda FP, Dearborn JH (1991) Feeding ecology of benthic mobile predators: experimental analyses of their influence in rocky subtidal communities of the Gulf of Maine. J Exp Mar Biol Ecol 149:13-44

Palmer AR (1990) Effects of crab effluent and scent of damaged conspecifics on feeding, growth, and shell morphology of the Atlantic dogwhelk Nucella lapillus (L.). Hydrobiologia 93:155-182

Peterson CH, Renaud PE (1989) Analysis of feeding preference experiments. Oecologia 80:82-86

Raubenheimer D, Cook P (1990) Effects of exposure to wave action on allocation of resources to shell and meat growth by the subtidal mussel, Mytilus galloprovincialis. J Shellfish Res 9:87-93

Reimer O, Harms-Ringdahl S (2001) Predator-inducible changes in the blue mussels from the predator-free Baltic Sea. Mar Biol 139:959-965

Reimer O, Tedengren M (1996) Phenotypical improvement of morphological defenses in the mussel Mytilus edulis induced by exposure to the predator Asterias rubens. Oikos 75:383-390

Riessen HP (1992) Cost-benefit model for the induction of an antipredator defense. Am Nat 140:349-362

Roa R (1992) Design and analysis of multiple-choice feedingpreference experiments. Oecologia 89:509-515

SAS (1996) SAS/STAT user's guide, release 6.3. SAS Institute, Cary, NC

Editorial responsibility: Otto Kinne (Editor),

Oldendorf/Luhe, Germany
Seed R (1968) Factors influencing shell shape in the mussel Mytilus edulis. J Mar Biol Assoc UK 48:561-584

Seed R (1976) Ecology. In: Bayne BL (ed) Marine mussels: their ecology and physiology. Cambridge University Press, Cambridge, $p$ 13-65

Serra G, Chelazzi, G, Castilla, JC (1997) Effects of experience and risk of predation on the foraging behaviour of the South-Eastern Pacific muricid Concholepas concholepas (Mollusca: Gastropoda). J Anim Ecol 66:876-883

Skelly DK, Werner EE (1990) Behavioral and life-historical responses of larval American toads to an odonate predator. Ecology 71:2313-2322

Smith LD, Jennings JA (2000) Induced defensive responses by the bivalve Mytilus edulis to predators with different attack modes. Mar Biol 136:461-469

Soto RE (1996) Estructura gremial de un ensamble de depredadores de la zona intermareal rocosa en Chile central. Invest Mar 24:97-105

Soto RE (2001) Decisiones de forrajeo del gastrópodo murícido Nucella crassilabrum: rol de los componentes asociados a las restricciones fisiológicas, experiencia ingestiva y al riesgo de mortalidad. $\mathrm{PhD}$ thesis, Pontificia Universidad Católica de Chile, Santiago

SPSS (1999) SigmaScan ${ }^{\circledR}$ Pro 5.0 user's guide. SPSS, Chicago, Illinois

Steffani CN, Branch GM (2003) Growth rate, condition, and shell shape of Mytilus galloprovincialis: responses to wave exposure. Mar Ecol Prog Ser 246:197-209

Suchanek TH (1978) The ecology of Mytilus edulis L. in exposed rocky intertidal communities. J Exp Mar Biol Ecol 31:105-120

Tollrian R, Harvell CD (1999) The ecology and evolution of inducible defenses. Princeton University Press, Princeton, NJ

Trussell GC (1996) Phenotypic plasticity in an intertidal snail: the role of a common crab predator. Evolution 50: 448-454

Yoshioka PM (1982) Predator-induced polymorphism in the bryozoan Membranipora membranacea. J Exp Mar Biol Ecol 61:233-242

Submitted: December 8, 2003; Accepted: April 16, 2004

Proofs received from author(s): July 12, 2004 